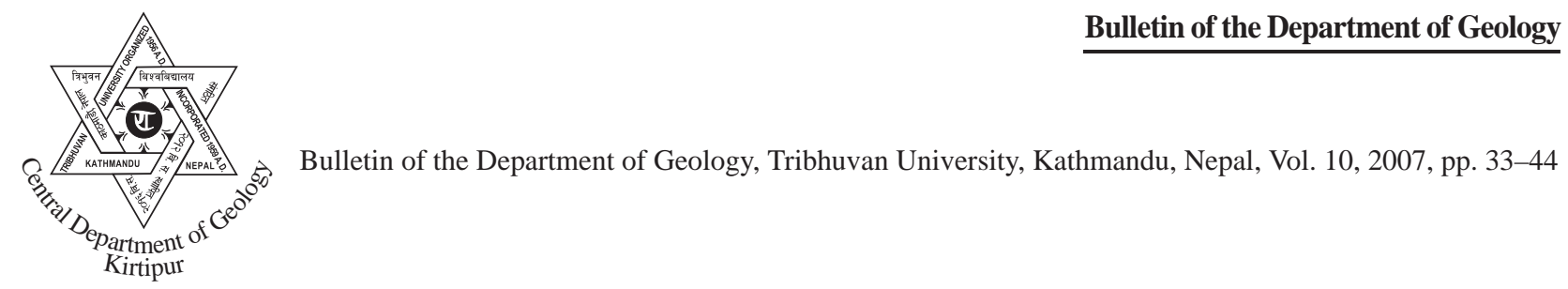

\title{
Bank erosion process and bank material loss potential in Manahara River, Kathmandu, Nepal
}

\author{
*Pramila Shrestha and Naresh Kazi Tamrakar \\ Central Department of Geology, Tribhuvan University, Kirtipur, Kathmandu, Nepal
}

\begin{abstract}
The Manahara River, one of the largest tributaries of the Bagmati River has been suffering from bank erosion problem and lateral shifting. Several erosional processes have been observed. Bank erosion causes loss of large amount of sediment from the watershed. The river has been assessed to find out major erosional processes to determine the relative annual sediment displaced from bank and recession rate of bank, the annual riverbank material loss was calculated using data from cross-sectional surveys of two runoff periods one is in 2005 and another is 2006, and using the factors related to bank material, bank vegetation and bank morphology. The major erosional processes identified are rill erosion, gully erosion, sheet erosion, parallel flow erosion and impinging flow erosion and slumping. Absolute bank material loss estimated from cross-sectional survey indicates that percent loss of sediment per cross-section correlates positively with downstream distance. With increase in distance from the origin, sediment gain or loss from transects also increases. The percent gain in downstream portion exceeds percent loss, therefore the river is aggrading. Contrarily, there is no correlation between distance and bank material loss. This indicates that bank material loss at the sites probably depends on local factors (riparian vegetation, bank material, bank morphology and sinuosity) other than the distance of origin of the river. Relative bank material loss assessed at 24 banks undergoing erosion results, $705 \mathrm{~m}^{3}$ sediment depleted annually from banks and mass of displaced material (TDM) is 1243 tons. The total volume and weight of sediment displaced from the Manahara River must be much higher than this value.
\end{abstract}

\section{INTRODUCTION}

Stream bank erosion is a dynamic and natural process as stream meanders across the landscape, however, in many places the rate of stream bank erosion has increased markedly because of hydraulic and geotechnical processes (Rosgen 2001). Stream bank erosion may be considered as either a hydraulic or a geotechnical process. Erosion refers to hydraulic process where individual soil particles at the bank surface are carried away by fluid flow, whereas erodibility is a function of bank material, bank morphology and bank vegetation. Tractive force increases as the slope, velocity and water depth increases in stream. Therefore erosive force is higher at higher flow.

The Manahara River has been suffering from bank erosion. Streambanks have been eroded

*Corresponding author:

E-mail address: smileprami@hotmail.com annually, and therefore several tons of bank materials are thought to be eroded and removed from the Manahara River Basin (MRB) annually. Among the sediments eroded away from the MRB, majority of sediment load may have been derived from banks of the river. Banks of this river are highly susceptible to erosion even on normal flow condition since majority of banks are composed of unconsolidated sedimentary deposits (Shrestha 2007). Therefore, this paper focuses on assessment of different erosional processes to understand its distribution patterns, and to evaluate relative annual sediment loss from banks of the Manahara River.

\section{GEOLOGICAL OUTLINES}

The Manahara River is one of the largest tributaries of the Bagmati River (Fig. 1) in the Kathmandu Basin in the Lesser Himalaya. It is an elongated basin that stretches for about $28 \mathrm{~km}$ from northeast to southeast. The northern catchment of 


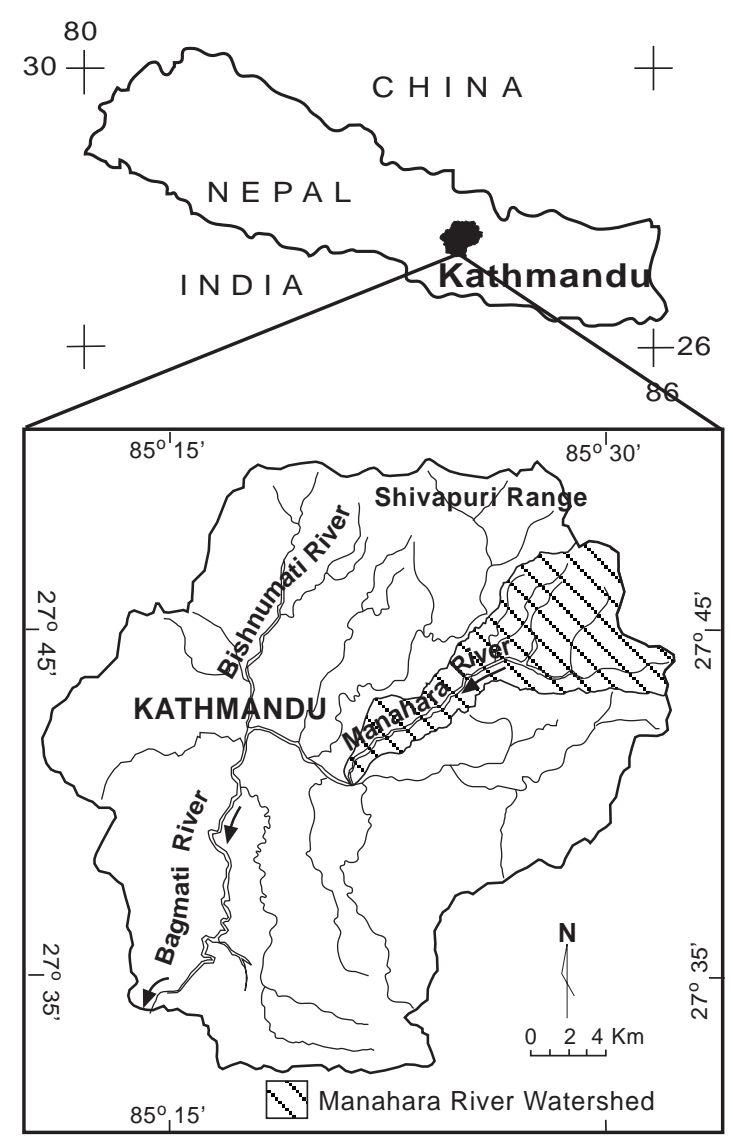

Fig. 1 Location map of study area

MRB lies in the Shivapuri Range composed of gneiss, granitic gneiss and pegmatite (Ohta 1973). The eastern and southeastern catchments comprise of quartzite and schist of the Kulekhani Formation and phyllite and metasandstone of the Tistung Formation (Stöcklin and Bhattarai 1977). The fluvio-lacustrine sediment of late Pleistocene age (Yoshida and Igarashi 1984) is distributed in the southern and western regions (Fig. 2).

The Manahara River is fifth order stream. It flows over hard rocks and forms a deep and narrow valley upto fourth order stretch. Then it changes into fifth order after joining with the Ghatte Khola near Sankhu. The fifth order stream flows over the unconsolidated sedimentary deposits and meanders forming wide floodplains. At recent time the river wanders actively in a wide valley because of systemwide instability (Bajracharya 2006). Bajracharya (1992) related the evolution of present MRB with neotectonics, and reported that the present courses of the Manahara and the Bagmati Rivers have been developed due to the rise of the Mahabharat Range, and also reported several northwest-southeast lineaments and a prominent Manahara Fault extending parallely along the major axis of the mainstream (Bajracharya 1992).

\section{METHODS}

The major types of erosion contributing bank erosion and sediment loss from the river were mapped on the scale of 1:10,000 with the help of aerial photo $(1: 15,000)$ and field survey. Absolute bank material loss and recession rate were obtained by crosssectional survey at eight riffles at four representative segments as Sankhu, Kurthali, Mulpani and Sano Thimi, respectively from upstream to downstream (Fig. 3), and in two runoff periods, 2005 and 2006. Relative bank material loss was surveyed at 24 eroding banks (Fig. 3) considering five major parameters, and later on amount of total sediment displaced from 24 banks was calculated.

\section{Absolute bank material loss assessment}

For calculation of bank material loss, the first cross-sectional survey was conducted in 2005 May (before monsoon). From this cross-section all morphologic parameters were calculated, evaluated and analysed. Afterward cross-sections were resurveyed using same procedure in February 2006 (after monsoon) to calculate and evaluate annual bank material loss, and sediment gain and loss in each cross-section. From the two seasonal profiles of the same location, necessary parameters were calculated and evaluated (Fig. 4). Pecent gain and percent loss of sediment from each cross-section were calculated as below:

$$
\begin{aligned}
& \% \text { Gain }=\left(\mathrm{A}_{\mathrm{G}} / \mathrm{A}_{\mathrm{TG}}\right) 100 \\
& \text { \%Loss }=\left(\mathrm{A}_{\mathrm{L}} / \mathrm{A}_{\mathrm{TL}}\right) 100
\end{aligned}
$$

where, $\mathrm{A}_{\mathrm{G}}=$ Total sediment gain in a transect, $\mathrm{A}_{\mathrm{TG}}=$ Total sediment gain in all the transects, $\mathrm{A}_{\mathrm{L}}=$ the total sediment loss in a transect and $\mathrm{A}_{\mathrm{TL}}=$ the total sediment loss in all the transects.

\section{Relative bank material loss assessment}

Relative bank material loss was assessed considering six major parameters around selected 
Bank erosion process and bank material loss potential in Manahara River, Kathmandu, Nepal

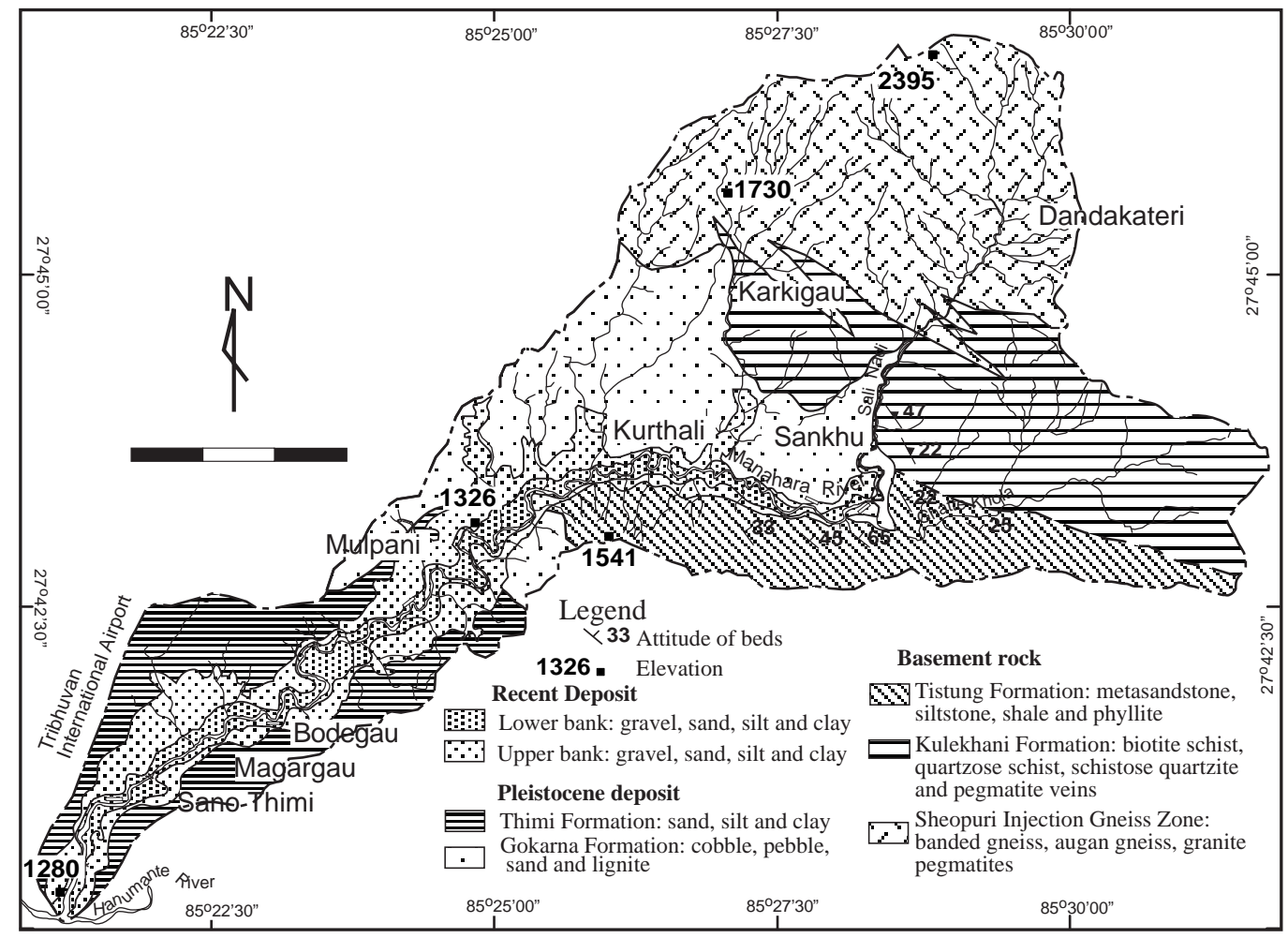

Fig. 2 Geological map of the Manahara River Basin

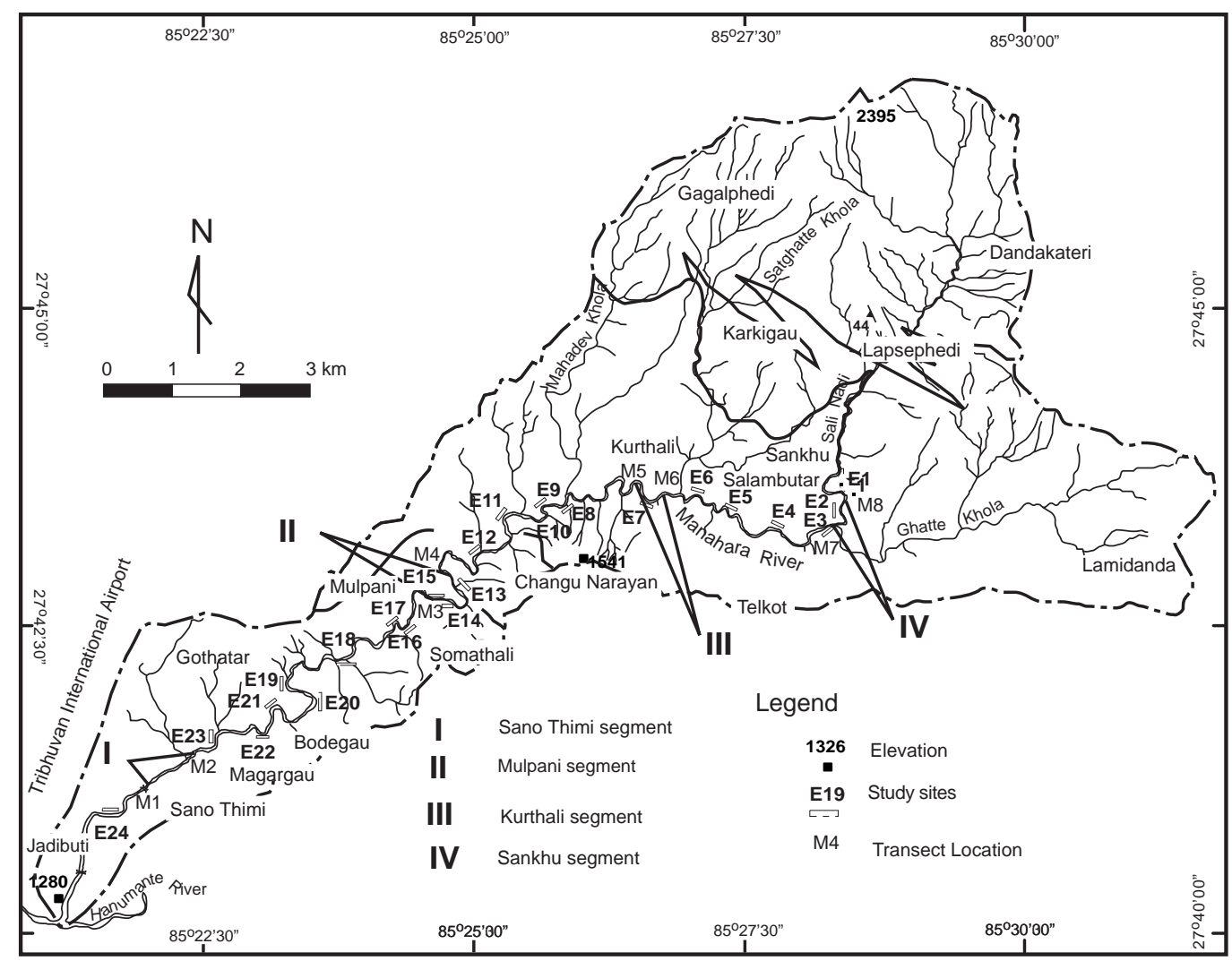

Fig. 3 Location of sampling sites and segments 


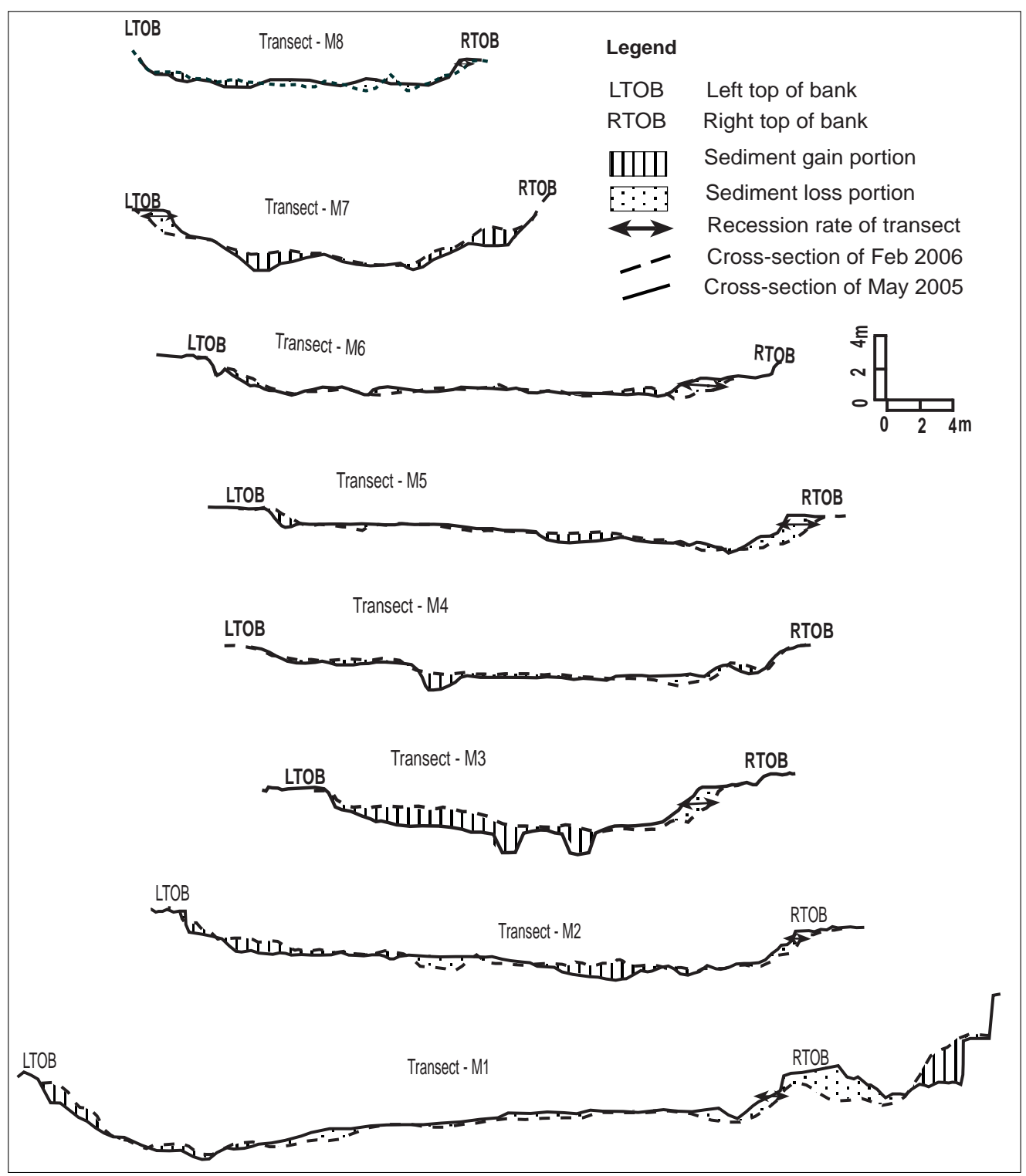

Fig. 4 Cross-sections of the Manahara River recorded in May 2005 and Feb 2006

study sites (Fig. 3). These parameters included soil texture, stream alignment, vegetation at top of the bank, bank slope, slope of inside depositional bar and stream gradient. The field observed parameters of bank erosion were then grouped into different ratings as shown in Table 1 .

The recession rate (RRs) is an estimation of the number of meter the bank material is likely to recede in a year. It is not an absolute value, but it gives only comparative recession rate for different stretches of the river. For estimation of recession rate, it was initially assumed that the maximum loss was $0.3 \mathrm{~m}$ per year. This assumption was based on the figure of $1 \mathrm{ft}$ of recession taken in common practice. All the estimated field parameters were converted into a fixed rating and all these ratings were multiplied to get RRs as

$$
\mathrm{RRs}=\mathrm{T} \mathrm{S} \mathrm{V} \mathrm{G} \mathrm{B} \mathrm{B}_{2}
$$

Where, $\mathrm{T}=$ Soil texture, $\mathrm{S}=$ Stream alignment, $\mathrm{V}=$ Vegetation at top of bank, $\mathrm{G}=$ Stream gradient, $\mathrm{B}_{1}=$ Bank slope, $\mathrm{B}_{2}=$ Slope of inside depositional bar. Then, the volume of displaced materials $\left(V_{d}\right)$ in 
Table 1: Rating of factors contributing bank material loss

\begin{tabular}{|c|c|c|c|}
\hline \multirow{2}{*}{ Factors (Parameters) } & \multicolumn{3}{|c|}{ Ratings } \\
\hline & 0.3 & 0.6 & 1 \\
\hline Soil Texture (T) & Clay, silty clay, silt loam & Sandy clay, loam, silt loam & Loamy sands, gravel \\
\hline Stream alignment (A) & Slightly to slightly curved & Moderately curved & Sharply curved, nearly $90^{\circ}$ \\
\hline Vegetation at top of bank (V) & Trees & Weeds, grass, shrubs & Crop, pasture, lawn, road \\
\hline Stream gradient $(\mathrm{G})$ & Slightly (few to no riffle) & $\begin{array}{l}\text { Moderately curved (balance of } \\
\text { riffle and pool) }\end{array}$ & High (primarily riffle) \\
\hline Bank slope $\left(B_{1}\right)$ & Slight (3:1 or less) & Moderate $(<3: 1$ but $>1: 1)$ & Steep (1:1 to vertical) \\
\hline Slope of inside depositional bar $\left(\mathrm{B}_{2}\right)$ & Steep $(>3: 1)$ & Moderate $(<3: 1$ but $>10: 1)$ & Slight $(<10: 1)$ \\
\hline
\end{tabular}

$\mathrm{m}^{3}$ has been calculated using following formula

$$
\mathrm{V}_{\mathrm{d}}=\text { RRs L H }
$$

where, $\mathrm{L}=$ Length of eroding bank $(\mathrm{m})$ and $\mathrm{H}=$ Height of eroding bank (m). In order to get tons of erosional loss per year, we used the following formula

$$
\mathrm{TDM}=\left(\mathrm{V}_{\mathrm{d}}\right) / 1000
$$

where, $\mathrm{TDM}=$ Tons of depleted material, $\mathrm{V}_{\mathrm{d}}=$ Volume of displaced material $\left(\mathrm{m}^{3}\right), \quad=$ Average density of material $\left(\mathrm{kg} / \mathrm{m}^{3}\right)$, which were considered $1282 \mathrm{~kg} / \mathrm{m}^{3}$ for silt \& clay, $1442 \mathrm{~kg} / \mathrm{m}^{3}$ for loam, $1602 \mathrm{~kg} / \mathrm{m}^{3}$ for sand, $1922 \mathrm{~kg} / \mathrm{m}^{3}$ for gravel.

\section{RESULTS}

\section{Distribution of bank erosion processes}

The bank erosion and failure processes, which were recognized in MRB, can be categorized as subaerial erosion, scour (mainly sub-aqueous), and mass failure. The distribution of various types of erosional processes is shown in Fig. 5.

\section{Sub-aerial erosion}

Rill and gully erosion occur generating a channelised flow pattern, when runoff is high during high discharge period. In sheet erosion, soil of surface layer is removed by a thin sheet of surface runoff. Commonly, gully erosion is found in third and fourth order stretches. Rill erosion occurs remarkably in the banks of the Sali Nadi (fourth order mainstem). In this stretch, rill erosion on the granites and gneissic rocks produces corugated appearence in the banks. Rill erosion is also observed at terraces of fluviolacustrine sediments and metasedimentary rocks of the Tistung Formation. Rill and sheet erosion often occur in fifth order stream where not only the riparian vegetation is lean but also irrigation, cultivation, and mining affects bank material (Fig. 6a). Some other processes contributing erosion of the bank material are slaking, rain splash and rill development, and stock trampling. The streambanks of the Manahara River are susceptible to subaerial erosion because of unconsolidated bank material and poor riparian vegetation.

\section{Scour}

Scour is a direct removal of bank material by the mechanical action of flowing water and sediment mixture. Scour of riverbed and bank is common in the Manahara River and it occurs due to impinging flow erosion and parallel flow erosion. Impinging flow erosion is detachment and removal of grains by the flow attacking a bank at a steep angle. Evidences of impinging flow are documented at about entire length of the river from upstream to downstream. At upstream stretches such phenomenon occurs mainly due to deflection caused by large debris in channel and turbulence generated down the step. At downstream stretches, between Sankhu and Jadibuti areas impinging flow occurs where tight meander bends occurs (Fig. 6b). Parallel flow is another scour phenomenon in which flow parallel to bank face takes away bank material. Such occurs when flow velocity is high. Parallel flow erosion (Fig. 6c) also occurs from upstream to downstream stretches. 
P. Shrestha and N. K. Tamrakar/ Bulletin of the Department of Geology, Vol. 10, 2007, pp. 33-44
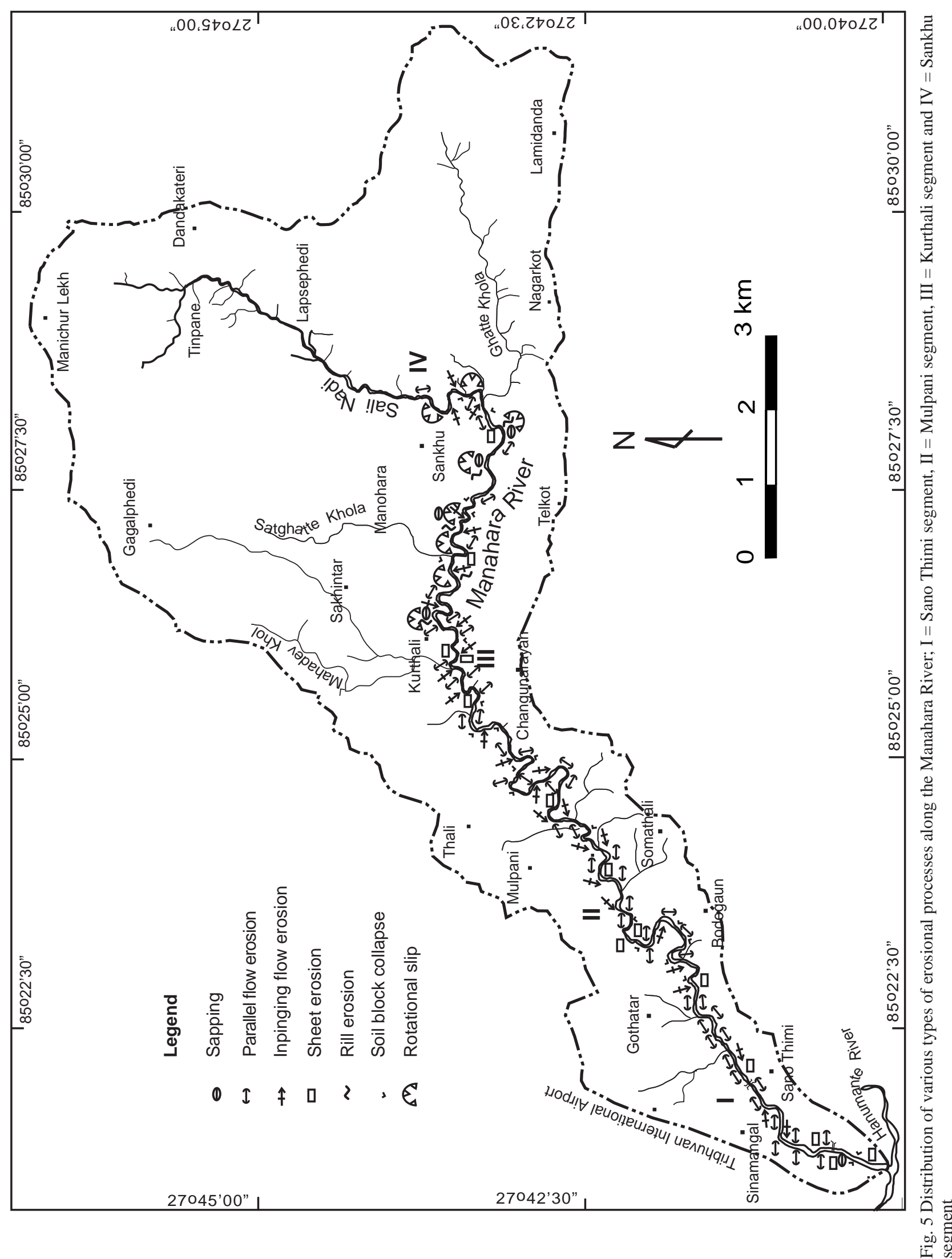

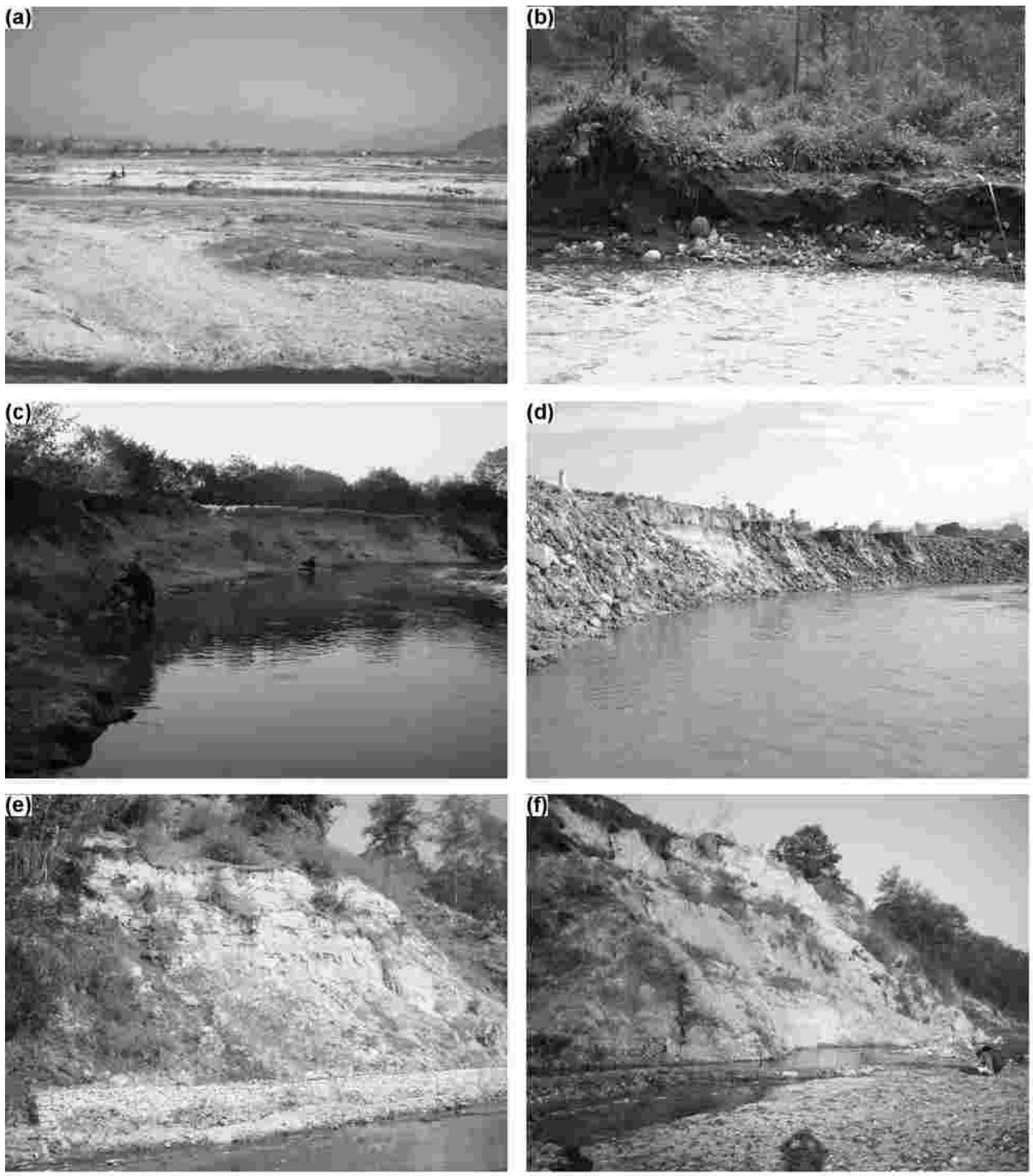

Fig. 6 Photographs: (a) Floodplain prone to sheet erosion near Bodegaun, (b) Bank scouring by impinging flow erosion at the left bank of the Sali Nadi near Sankhu, (c) Bank scouring due to parallel flow erosion near Chapro (upstream view), (d) Slumping of streambank near Bodegaun (downstream view), (e) Slumping present at the left bank of the river downstream from Kurthali, and (f) Large-scale slumping at the left bank of the Manahara River at Salambutar 
Bank scouring is observed through out the river corridor and bed scouring is basically concentrated in upstream stretches between Dandakateri and Sankhu areas where river has high gradient and flows over bedrock, where stream is in youth-full stage and has tendency of headward erosion. Headward erosion is potential for bank erosion at Mulpani and Sano Thimi areas where mining of the riverbed has been continuing for many years.

In the Manahara River, bank scouring contributes slumping, which is accelerated throughout the river corridor. In most of the segments, a small-scale slumping, due to toe undercutting by river flow is present (Fig. 6d). But at some locations as in Kurthali and Sankhu areas, a large-scale slumping is present. Most of these landslides are observed in terraces of the fluvio-lacustrine sediments existed as the banks of the river (Fig. 6e). These landslides are triggered by groundwater seepage present at the contact of black clay layer and coarse-grained sand. The slumping observed near Salambutar is about $50 \mathrm{~m}$ high and $>100 \mathrm{~m}$ long (Fig. 6f). Other large-scale slumpings are observed near Kurthali at the base of the Telkot Hills, at the confluence between the Sali Nadi and the Ghatte Khola at Sankhu.

\section{Absolute bank material loss}

Amount of sediment gain from transects M8 and M7 (Sankhu segment) are $12.80 \mathrm{~m}^{2}$ and $3.20 \mathrm{~m}^{2}$ and loss are $5.40 \mathrm{~m}^{2}$ and $5.20 \mathrm{~m}^{2}$ respectively. Similarly, transects M6 and M5 (Kurthali segment) achieve 8.6 $\mathrm{m}^{2}$ and $3.0 \mathrm{~m}^{2}$ loose $11.4 \mathrm{~m}^{2}$ and $17.0 \mathrm{~m}^{2}$ respectively. Likewise transects M4 and M3 (Mulpani segment) gain $12.4 \mathrm{~m}^{2}$ and $25.0 \mathrm{~m}^{2}$ and loose $10.0 \mathrm{~m}^{2}$ and 23.4 $\mathrm{m}^{2}$. Also, M2 and M1 (Sano Thimi segment) gain $36.6 \mathrm{~m}^{2}$ and $32.6 \mathrm{~m}^{2}$ and loose $14.80 \mathrm{~m}^{2}$ and 58.0 $\mathrm{m}^{2}$, respectively.

The results of profile survey are shown in Table 2. In totality, Sankhu, Mulpani and Sano Thimi segments gain cross-sections while Kurthali segment looses it. But considering the streambanks only, M4 (Mulpani segment) and M6 (Kurthali segment) indicate greater proportion of bank material loss out of total crosssection. Therefore, in both Kurthali and Mulpani segments, bank loss potential seems to be higher compared to other segments.

Regarding average width of bank loss per year, the transect M6 (Kurthali segment) had the highest width of bank loss $(2.2 \mathrm{~m} / \mathrm{yr})$ and transect M4 (Mulpani segment) had the lowest width of bank loss $(0.4 \mathrm{~m} / \mathrm{yr})$. But, according to field observation bank

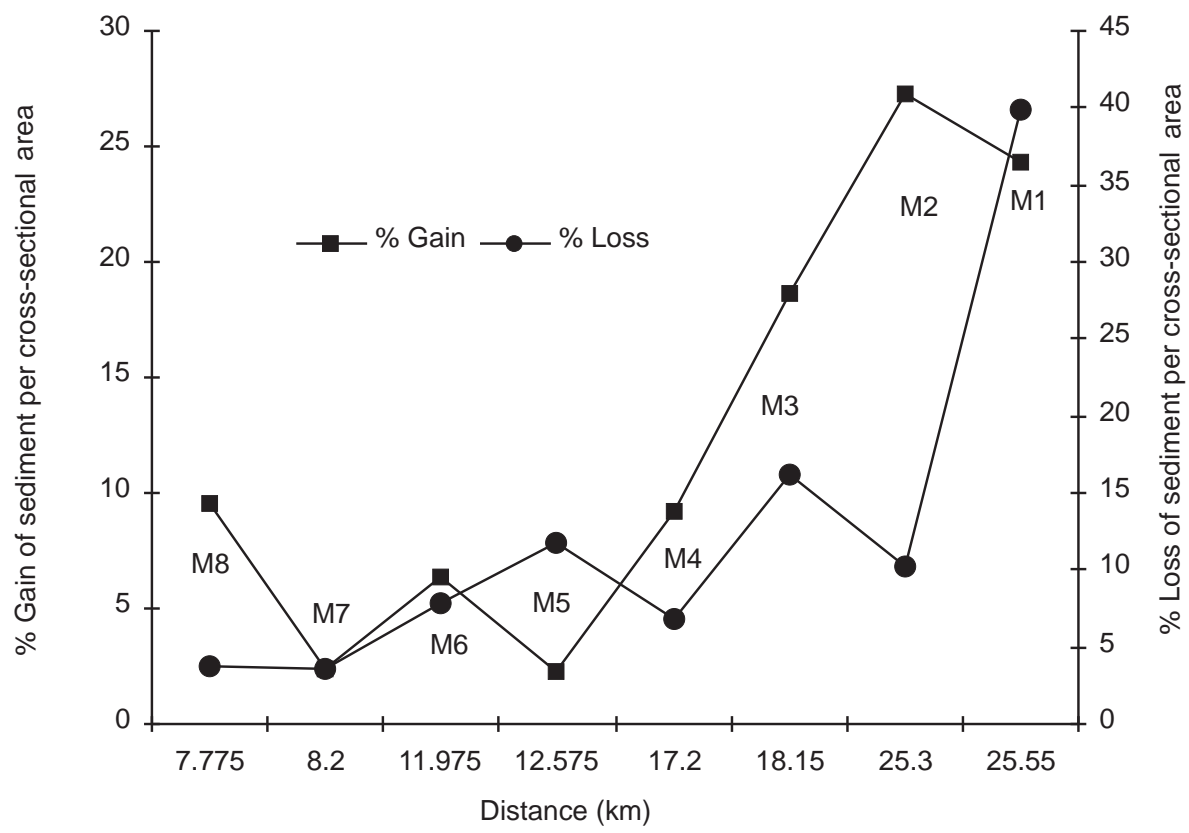

Fig. 7 Amount of sediment loss and gain from different transects of the Manahara River 
Table 2: Percent gain and percent loss of sediment at each cross-section

\begin{tabular}{ccccccccc}
\hline Transect & $\begin{array}{c}\text { Distance } \\
\text { Form Origin }\end{array}$ & $\begin{array}{c}\text { Stream } \\
\text { Width }(\mathrm{m})\end{array}$ & $\begin{array}{c}\text { Sediment Gain }\left(\mathrm{m}^{2}\right) \\
\text { per cross-section }\end{array}$ & $\begin{array}{c}\text { Gediment Loss }\left(\mathrm{m}^{2}\right) \\
\text { Gain }\end{array}$ & $\begin{array}{c}\text { Ser Loss } \\
\text { perss-section }\end{array}$ & $\begin{array}{c}\text { Bank Material } \\
\text { Loss }\left(\mathrm{m}^{2}\right)\end{array}$ & $\begin{array}{c}\text { Recession } \\
\text { Rate }(\mathrm{m} / \mathrm{yr})\end{array}$ \\
\hline M1 & 25.55 & 15.20 & 32.60 & 24.29 & 58.00 & 39.94 & 5.00 & 1.40 \\
M2 & 25.30 & 16.40 & 36.60 & 27.27 & 14.80 & 10.19 & 1.00 & 0.60 \\
M3 & 18.15 & 26.00 & 25.00 & 18.63 & 23.40 & 16.12 & 9.80 & 2.20 \\
M4 & 17.20 & 30.80 & 12.40 & 9.24 & 10.00 & 6.89 & 10.40 & 2.00 \\
M5 & 12.58 & 24.20 & 3.00 & 2.24 & 17.00 & 11.71 & 1.60 & 0.40 \\
M6 & 11.98 & 23.60 & 8.60 & 6.41 & 11.40 & 7.85 & 10.80 & 1.60 \\
M7 & 8.20 & 38.00 & 3.20 & 2.38 & 5.20 & 3.58 & 4.40 & 0.70 \\
M8 & 7.78 & 46.00 & 12.80 & 9.54 & 5.40 & 3.72 & 0.80 & 1.00 \\
Total & & & 134.20 & & 145.20 & & & \\
\hline
\end{tabular}

erosion and bank recession rate are high at pool rather than riffle section of river. The riffle section of river seems as area of least erosion. Also the width of bank loss as obtained in this study for one year period does not represent the actual magnitude of bank loss observed in the study area which would be the average of several years of observation.

Also percent of loss of sediment per cross-sectional area correlates positively with downstream distance. With increase in distance from origin, percent gain and percent loss of sediment from transects also increase (Fig. 7). The percent gain in downstream portion exceeds percent loss, therefore the river is aggrading therein. On the other hand there is no correlation between distance and bank material loss. This indicates that probability of bank material loss depends on local factors other than the distance of origin of the river.

\section{Relative bank material loss \\ Bank material texture}

Almost all of the banks of the Manahara River are composed of non cohesive silt, sand, gravel and cobbles (Figs. 8a \& b), except at the locations where river flows through bed rock and black clay. The bank material texture of all studied sites falls on rating 1 , indicating high susceptibility for erosion (Table 3).

\section{Stream alignment}

From Manichur Lekh to Sankhu area (up to the fifth order mainstem), the Manahara River has straight alignment with least potential of bank erosion. But, when it starts to flow over loose and unconsolidated substrate it becomes a meandering river forming several meander bends. So, bank erosion is mostly confined in this stretch (Fig. 8b). Therefore stream alignment is one of the criteria for assessing bank material loss potential. Ratings of stream alignment fall on 0.6 to 1 .

\section{Stream gradient}

Higher and larger the stream gradient, the greater the rate of flow and the greater the potential for stream bank erosion. In the MRB, third order mainstem has high gradient $(0.070 \mathrm{~m} / \mathrm{m})$ with primarily riffle. The fourth order mainstream has riffle and the fifth order stream has repeated pools and riffles indicating moderate stream gradient. Most of assessed sites fall on 0.6 rating.

\section{Vegetation at top of bank}

Large trees and/or thick woody vegetation tightly bordering streambanks usually prevent erosion. Some bank protection is provided by the tree root system. Shallow rooted vegetation or absence of vegetation provides no protection to banks and therefore indicates probability of higher erosion rates. The banks of fourth order stream are covered by large trees providing canopy with deep root system, understory trees and shrubs, and ground cover grasses. So, river banks up to fourth order are less pronounced for bank erosion. Fifth order segment posses bank vegetation of grass with some patches of shrubs. Hence, bank erosion risk ratings of almost all studied sites falls on rating 1 . 

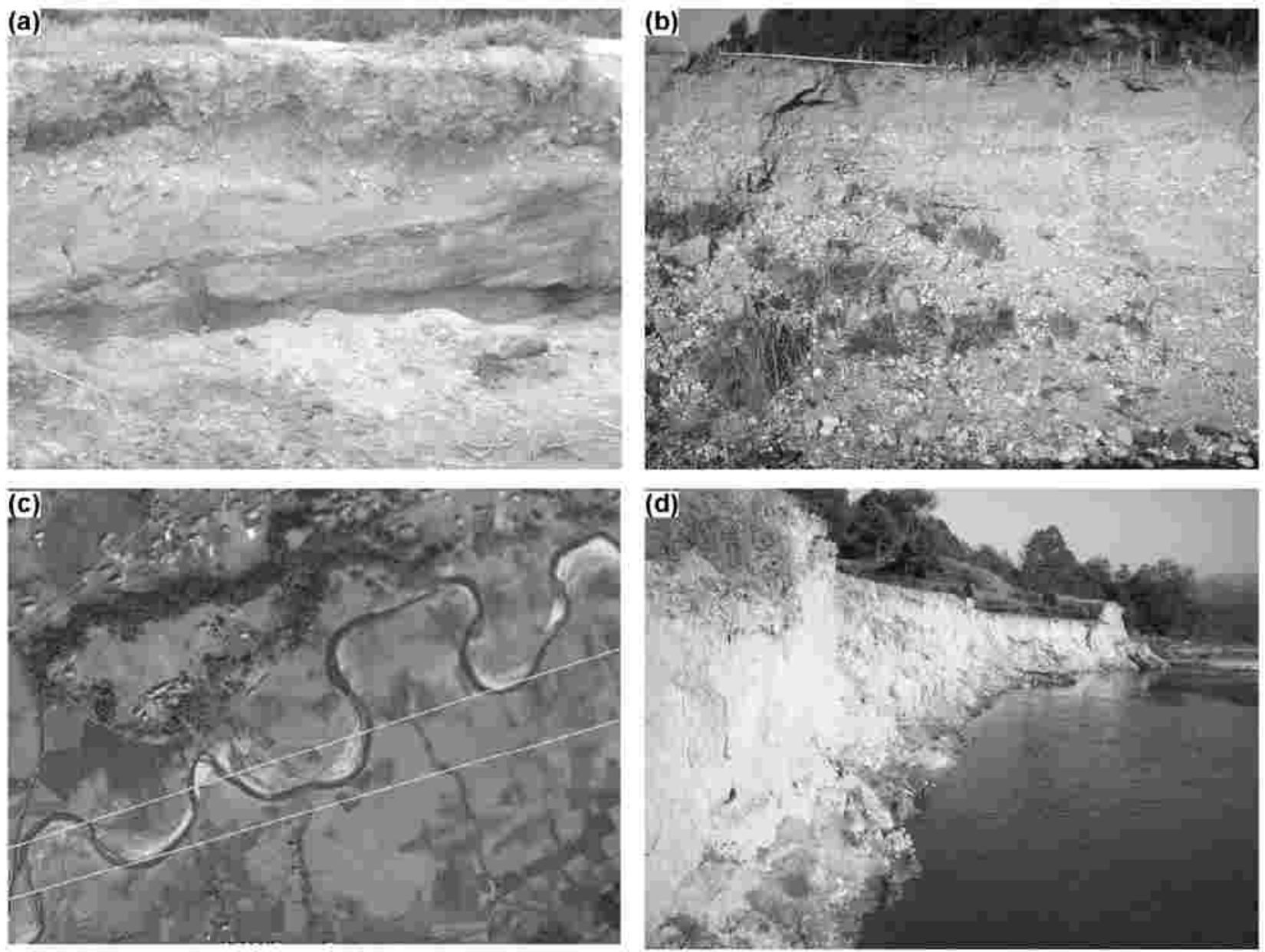

Fig. 8 Photographs showing nature of bank material in the Manahara River: (a) Non-cohesive bank material present in the right bank near Bodegaun, (b) Non-cohesive bank material present at the right bank near Kurthali, (c) Alignment of the river around Salambutar area showing sharply meandering bends, and (d) Eroding bank present at the right bank of the river near Salambutar showing rapid rate of erosion (upstream view)

\section{Bank slope}

The slope of an eroding bank is an indicator of erosion rate. A vertical slope or undercut bank generally means a high rate of erosion. The lesser the slope of the eroding bank, lower the erosion potential.

Slope of eroding bank is very steep. At most of the areas very steep scarps and undercutting banks are present (Fig. 6c), which are thickly distributed along the Manahara River indicating high susceptibility of bank erosion. Bank erosion risk rating of studied sites falls on 0.6 to 1 rating.

\section{Slope of inside depositional bar}

As erosion occurs on the outside edge of a bend in a stream, deposition occurs on the inside potion. The slope of depositional bar is indicative of the rate of erosion. An additional indicator is the presence or absence of vegetation on the depositional bar. A lack of vegetation signifies a rapid erosional rate. Point bars of twenty four sites have very gentle slope (1015 degrees) and absence of vegetation indicating rapid rate of erosion (Fig. $8 \mathrm{~d}$ ). The bank erosion risk ratings of all studied sites fall on rating 1 , indicating rapid rate of erosion.

The result show that bank material texture $(\mathrm{T})$ has value 1 . At most of the locations stream alignment (S) has value 0.6 and at some locations this value is 1. Vegetation present at banks of river (V) falls on rating 1 . The results obtained from the field evaluation were used to calculate recession rate and total volume of sediment displaced and tons of displaced material from bank of each transect. Result of field evaluation 
Table 3: Results of relative bank material loss assessment

\begin{tabular}{|c|c|c|c|c|c|c|c|c|c|c|c|c|c|}
\hline SN & Site & $\mathrm{T}$ & S & $\mathrm{V}$ & $\mathrm{G}$ & $\mathrm{B}_{1}$ & $\mathrm{~B}_{2}$ & $\begin{array}{l}\text { Recession } \\
\text { Rate, RRs }\end{array}$ & $\begin{array}{l}\text { RRs, } \\
\text { m/year }\end{array}$ & $\begin{array}{c}\text { Length of } \\
\text { Eroding Bank, L } \\
(\mathrm{m})\end{array}$ & $\begin{array}{c}\text { Height of } \\
\text { Eroding Bank, } \\
\text { H (m) }\end{array}$ & $\begin{array}{c}\text { Volume of } \\
\text { displaced material } \\
\left(\mathrm{m}^{3}\right)\end{array}$ & $\begin{array}{c}\text { Tons of Displaced } \\
\text { Material (TDM) }\end{array}$ \\
\hline 1 & E1 & 1.0 & 0.6 & 1.0 & 0.6 & 0.6 & 1.0 & 0.22 & 0.06 & 6 & 0.8 & 0.31 & 0.55 \\
\hline 2 & E2 & 1.0 & 0.6 & 1.0 & 0.6 & 0.3 & 1.0 & 0.11 & 0.03 & 28 & 4.35 & 3.95 & 6.96 \\
\hline 3 & E3 & 1.0 & 0.6 & 1.0 & 0.6 & 0.3 & 1.0 & 0.11 & 0.03 & 92 & 0.83 & 2.48 & 4.36 \\
\hline 4 & E4 & 1.0 & 0.6 & 1.0 & 0.6 & 0.3 & 1.0 & 0.11 & 0.03 & 155 & 1.92 & 9.65 & 17.01 \\
\hline 5 & E5 & 1.0 & 1.0 & 0.6 & 0.6 & 0.3 & 1.0 & 0.11 & 0.03 & 73 & 9 & 21.31 & 37.55 \\
\hline 6 & E6 & 1.0 & 1.0 & 1.0 & 0.6 & 0.3 & 1.0 & 0.18 & 0.05 & 215 & 6 & 69.73 & 122.88 \\
\hline 7 & E7 & 1.0 & 0.6 & 1.0 & 0.6 & 0.3 & 1.0 & 0.11 & 0.03 & 155 & 0.95 & 4.78 & 8.42 \\
\hline 8 & E8 & 1.0 & 0.6 & 0.6 & 0.6 & 0.6 & 1.0 & 0.13 & 0.04 & 150 & 0.85 & 4.96 & 8.74 \\
\hline 9 & E9 & 1.0 & 0.6 & 0.6 & 0.6 & 0.6 & 1.0 & 0.13 & 0.04 & 5 & 0.8 & 0.16 & 0.27 \\
\hline 10 & E10 & 1.0 & 0.6 & 0.6 & 0.6 & 1.0 & 1.0 & 0.22 & 0.06 & 60 & 5.5 & 21.41 & 37.72 \\
\hline 11 & E11 & 1.0 & 0.6 & 1.0 & 0.6 & 0.3 & 1.0 & 0.11 & 0.03 & 115 & 0.87 & 3.24 & 5.72 \\
\hline 12 & E12 & 1.0 & 0.6 & 1.0 & 0.6 & 1.0 & 1.0 & 0.36 & 0.11 & 15 & 1.15 & 1.86 & 3.29 \\
\hline 13 & E13 & 1.0 & 0.6 & 1.0 & 0.6 & 1.0 & 1.0 & 0.36 & 0.11 & 17 & 1.2 & 2.21 & 3.89 \\
\hline 14 & E14 & 1.0 & 0.6 & 1.0 & 0.6 & 1.0 & 1.0 & 0.36 & 0.11 & 125 & 1.25 & 16.89 & 29.77 \\
\hline 15 & E15 & 1.0 & 0.6 & 1.0 & 0.6 & 1.0 & 1.0 & 0.36 & 0.11 & 135 & 1.85 & 27.00 & 47.58 \\
\hline 16 & E16 & 1.0 & 1.0 & 0.6 & 0.6 & 0.6 & 1.0 & 0.22 & 0.06 & 70 & 1.24 & 5.63 & 9.92 \\
\hline 17 & E17 & 1.0 & 0.6 & 1.0 & 0.6 & 1.0 & 1.0 & 0.36 & 0.11 & 65 & 4.5 & 31.62 & 55.72 \\
\hline 18 & E18 & 1.0 & 0.6 & 1.0 & 0.6 & 1.0 & 1.0 & 0.36 & 0.11 & 80 & 1.17 & 10.12 & 17.83 \\
\hline 19 & E19 & 1.0 & 0.6 & 1.0 & 0.6 & 1.0 & 1.0 & 0.36 & 0.11 & 45 & 1.05 & 5.11 & 9.00 \\
\hline 20 & E20 & 1.0 & 1.0 & 1.0 & 0.6 & 1.0 & 1.0 & 0.60 & 0.18 & 155 & 5 & 139.64 & 246.07 \\
\hline 21 & E21 & 1.0 & 0.6 & 1.0 & 0.6 & 1.0 & 1.0 & 0.36 & 0.11 & 800 & 1.77 & 153.08 & 269.76 \\
\hline 22 & E22 & 1.0 & 0.6 & 1.0 & 0.6 & 1.0 & 1.0 & 0.36 & 0.11 & 350 & 1.74 & 65.84 & 116.02 \\
\hline 23 & E23 & 1.0 & 0.6 & 1.0 & 0.6 & 1.0 & 1.0 & 0.36 & 0.11 & 400 & 2.4 & 103.78 & 182.89 \\
\hline 24 & E24 & 1.0 & 0.6 & 0.6 & 0.6 & 1.0 & 1.0 & 0.22 & 0.06 & 5 & 1.65 & 0.54 & 0.94 \\
\hline & & & & & & & & & \multicolumn{3}{|c|}{ Total sediment displaced } & 705.29 & 1242.86 \\
\hline
\end{tabular}

and calculation is given in Table 3. Total volume of displaced material from assessed 24 transects is 705 $\mathrm{m}^{3}$ and weight of total sediment transport is 1243 tons. The obtained volume of displaced material and tons of displaced material of all 24 locations also increase generally towards downstream. But, total volume and weight of sediment transported from the Manahara River must be much higher than these 24 evaluated sites.

\section{DISCUSSIONS}

Various bank erosion processes contribute large amount of sediment loss from the watershed. Rill and gully erosions as well as sheet erosion are distributed in barren areas where land surfaces have sub-aerial exposure. Parallel and impinging flow erosion are pronounced where river bank is composed of non-cohesive materials as at Sankhu, Kurthali, Mulpani, Bodegaun and Sano Thimi areas. River segments, which have unconsolidated banks as in fifth order mainstem, are vulnerable to erosion even in normal flow condition. Several small- and largescale slumpings were found throughout the river corridor. Small-scale slumping was observed where banks height was low and toe undercutting by impinging flow occurred, whereas large-scale slumping was observed in terraces of fluvio-lacustrine deposits.

There is positive correlation between downstream distance and sediment gain or loss per cross-section. Percent gain in downstream stretch exceeds percent loss. This is probably due to increase in cross-sectional area and discharge, and decrease in slope of stream towards downstream stretch. Width of bank loss obtained from one year of record does not necessary mean the actual loss. Actual loss would be the product of number of streambank erosion sites, sterambank length and height, and the average of the long term records of tons of loss per year. There is no correlation between downstream distance and bank material loss, and downstream distance and RRs. This indicates that probability of bank material loss is not governed by distance from origin. 
The volume of displaced material tends to increase from upstream to downstream. Total apparent volume of sediment displaced from 24 locations is $705 \mathrm{~m}^{3}$ which weigh 1243 tons, which exhibit that if the RRs of the bank is $0.33 \mathrm{~m}$ per year, the total loss of sediment comes to be 1243 tons per year from 24 banks. However, this figure could have increased if several eroding banks were taken into account.

Major causes of bank erosion in MRB are rapid landuse change, vegetation clearance, lateral channel shifting, unconsolidated bank material, and extraction of sediment from streambed and streambank. Shrestha (2007) reported that landuse pattern of MRB changed rapidly with development. Within short interval of time landuse pattern has changed drastically. In year $1978,87.86 \%$ of land was covered by forest, but upto year 2002, forest area has reduced to $17.22 \%$ only. Similarly, lateral channel shifting and meander migration was highly pronounced in this river as reported by Bajracharya (2006). Channel shifting is also another major cause of aggravating bank erosion., which is supported by unconsolidated bank material and neotectonic activities. Likewise, removal of channel and bank material is important factor for bank erosion and bank material loss (Tamrakar 2004), because extensive removal of stream sediment upsets equilibrium of the river. Besides, presence of seepage zone, deflection of rivers natural flow, disposal of solid and liquid waste to river, grazing activities are locally responsible for bank erosion.

\section{CONCLUSIONS}

1. Slumping dominantly occurs in high banks of Sankhu and Kurthali segments, whereas parallel and impinging flow erosion processes remarkably occur in Mulpani and Sano Thimi segments.

2. Amount of sediment gain and loss from transects increased with increasing distance from origin and percent gain in downstream portion exceeds percent loss signifying aggradation of river at downstream.

3. Bank material loss from each of the transects and the recession width of the streambanks do not depend on downstream distance, but are influenced by local factors such as bank material, riparian vegetation, bank morphology and sinuosity.

4. Relative bank material loss is 1243 tons/year for 24 study sites if RRs of bank is $0.33 \mathrm{~m}$ per year. This figure may change if several banks are taken into account for several years. The average relative bank loss would be 51.79 tons/year.

5. Rapid landuse change, vegetation clearance, lateral channel shifting, unconsolidated bank material, excavation of riverbed and riverbank sediment are major causes of bank erosion and sediment loss.

\section{ACKNOWLEDGEMENTS}

Authors are thankful to the Central Department of Geology for providing facility of field instruments. Authors thank R. Bajracharya and S. Maharjan for assistance during survey.

\section{REFERENCES}

Bajracharya, R., 2006. Study of geoenvironmental problems of the Manohara River, Kathmandu, Nepal. Unpublished M. Sc. Thesis submitted to Central Department of Geology, Tribhuvan University, Kathmandu, Nepal, $132 p$.

Bajracharya, S.R., 1992. Fluvial system of Kathmandu valley in relation to neotectonics. Bulletin of Department of Geology, Tribhuvan University, Kathmandu, v. 2, no. 1 , pp. 173-179.

Ohta, Y., 1973. Geology of the Nepal Himalayas. In: Geology of Himalayas, K. Arita, Y. Ohta, C. Akiba and Y. Mauro (eds.), Saikon Publication Co. Ltd., pp. 235-259.

Rosgen, D.L., 2001. A stream channel stability assessment methodology. In proceeding of the Seventh International Sedimentation Conference Reno, Nevada, March, pp. 25-28.

Shrestha, P., 2007. Streambank condition, erosion process and bank erodibility and lateral instability hazard along the Manahara River with reference to bank erosion hazard mapping. Unpublished M. Sc. Thesis submitted to Central Department of Geology, Tribhuvan University, Kathmandu, Nepal, 188p.

Stöcklin, J., and Bhattarai, K.D., 1977. Geology of the Kathmandu area and Central Mahabharat range, Nepal Himalaya. Report of Department of Mines and Geology/UNDP (unpublished report), 86p.

Tamrakar, N.K., 2004. Distrubances and instabilities in the Bisnumati River Corridor, Kathmandu Basin. Bulletin of Japanese University Student Association (jusan), Nepal, v.9, Issue 16, pp. 7-18

Yoshida, M. and Igarashi, Y., 1984. Neogene to quaternary lacustrine sediments in the Kathmandu Valley, Nepal, Journal of Nepal Geological Society, Special Issue, v. 4, pp. 73-100. 